Prepared in cooperation with the Bandera County River Authority and Groundwater District and the Texas Water Development Board

\title{
Flood-Inundation Maps for a 23-Mile Reach of the Medina River at Bandera, Texas, 2018
}

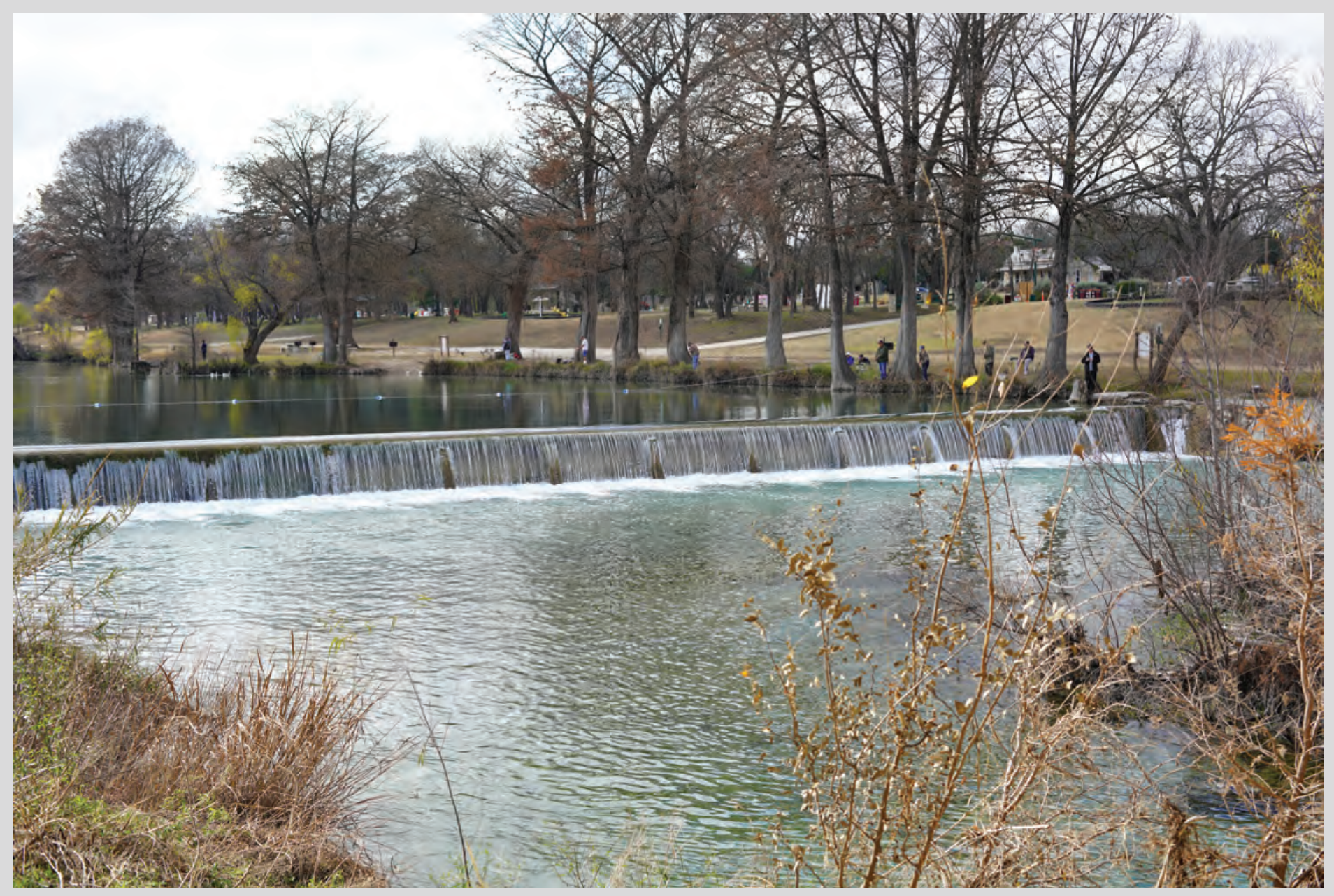

Scientific Investigations Report 2019-5067 
Front cover, West-oriented view of the Medina River looking upstream near State Route 16 in Bandera, Texas, December 2018 (photograph by Frank L. Engel, U.S. Geological Survey).

Back cover, Southwest-oriented view of the Bandera water supply tower near the Bandera County Courthouse, Bandera, Texas, December 2018 (photograph by Frank L. Engel, U.S. Geological Survey). 


\section{Flood-Inundation Maps for a 23-Mile Reach of the Medina River at Bandera, Texas, 2018}

By Namjeong Choi and Frank L. Engel

Prepared in cooperation with the Bandera County River Authority and

Groundwater District and the Texas Water Development Board

Scientific Investigations Report 2019-5067 


\title{
U.S. Department of the Interior \\ DAVID BERNHARDT, Secretary
}

\author{
U.S. Geological Survey \\ James F. Reilly II, Director
}

U.S. Geological Survey, Reston, Virginia: 2019

For more information on the USGS - the Federal source for science about the Earth, its natural and living resources, natural hazards, and the environment-visit https://www.usgs.gov or call 1-888-ASK-USGS.

For an overview of USGS information products, including maps, imagery, and publications,

visit https://www.usgs.gov/pubprod/.

Any use of trade, firm, or product names is for descriptive purposes only and does not imply endorsement by the U.S. Government.

Although this information product, for the most part, is in the public domain, it also may contain copyrighted materials as noted in the text. Permission to reproduce copyrighted items must be secured from the copyright owner.

Suggested citation:

Choi, N., and Engel, F.L., 2019, Flood-inundation maps for a 23-mile reach of the Medina River at Bandera, Texas, 2018: U.S. Geological Survey Scientific Investigations Report 2019-5067, 15 p., https://doi.org/10.3133/sir20195067.

ISSN 2328-0328 (online) 


\section{Acknowledgments}

The authors wish to thank the Bandera County Emergency Management Department, the Honorable Judge Richard Evans, and members of the public for their contributions and feedback during several stakeholder meetings over the course of this work. Special thanks are also given to the National Weather Service for their continued support of the U.S. Geological Survey Flood Inundation Mapping Program. 



\section{Contents}

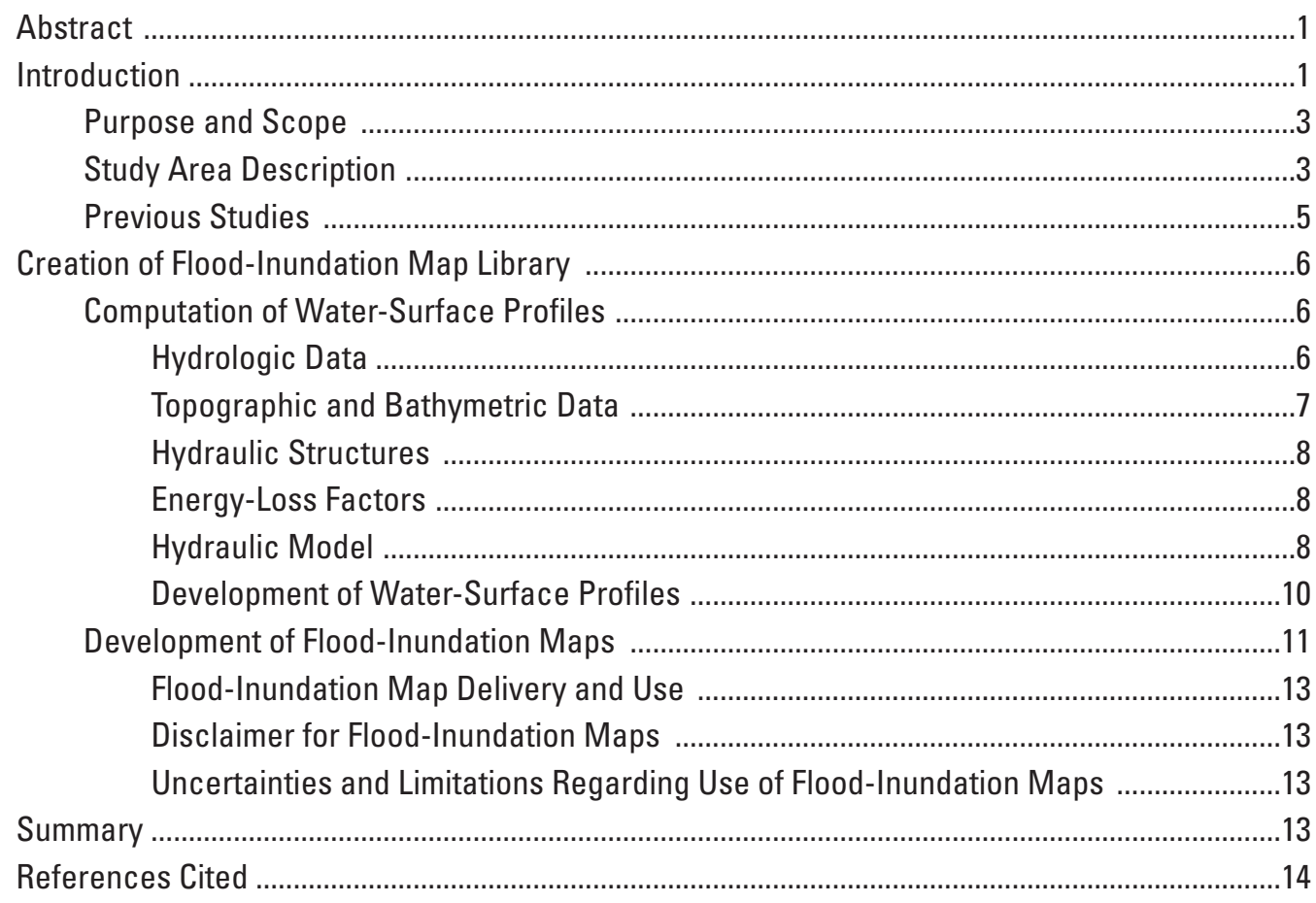

\section{Figures}

1. Map showing location of the study reach on the Medina River at and near Bandera, Texas, and locations of the nearest U.S. Geological Survey streamflowgaging stations

2. Photograph showing northeast-oriented view of the Medina River in flood stage at State Route 16 near Bandera, Texas, July 2002

3. Photograph showing U.S. Geological Survey (USGS) crews performing a crosssection survey near USGS streamflow-gaging station 08178880 Medina River at Bandera, Texas

4. Photograph showing U.S. Geological Survey (USGS) crews performing a crosssection survey at USGS streamflow-gaging station 08178980 Medina River above English Crossing near Pipe Creek, Texas

5. Map showing the modeled flood-inundation map for the Medina River at Bandera, Texas, corresponding to a stage of 38 feet at U.S. Geological Survey streamflowgaging station 08178880 


\section{Tables}

1. U.S. Geological Survey streamflow-gaging station information for the Medina River at and near Bandera, Texas .

2. Peak discharges for selected annual exceedance probabilities for the Medina River at and near Bandera, Texas .

3. Estimated discharges at the upstream end of the study reach and at the confluence of Bandera Creek with the Medina River, Texas, that were used in the hydraulic model and corresponding stages and water-surface elevations at U.S. Geological Survey streamflow-gaging station 08178880 Medina River at Bandera, Texas

4. Target water-surface elevations and modeled water-surface elevations used to calibrate the model at U.S. Geological Survey streamflow-gaging station 08178880 Medina River at Bandera, Texas

5. Observed stages and modeled stages for four flood events (March 20, 2012; May 26, 2014; May 23, 2015; and May 29, 2016) used for validation of the model at U.S. Geological Survey streamflow-gaging station 08178880 Medina River at Bandera, Texas 


\section{Conversion Factors}

U.S. customary units to International System of Units

\begin{tabular}{|c|c|c|}
\hline Multiply & By & To obtain \\
\hline \multicolumn{3}{|c|}{ Length } \\
\hline foot $(\mathrm{ft})$ & 0.3048 & meter $(\mathrm{m})$ \\
\hline mile (mi) & 1.609 & kilometer (km) \\
\hline \multicolumn{3}{|c|}{ Area } \\
\hline square mile $\left(\mathrm{mi}^{2}\right)$ & 2.590 & square kilometer $\left(\mathrm{km}^{2}\right)$ \\
\hline \multicolumn{3}{|c|}{ Flow rate } \\
\hline cubic foot per second $\left(\mathrm{ft}^{3} / \mathrm{s}\right)$ & 0.02832 & cubic meter per second $\left(\mathrm{m}^{3} / \mathrm{s}\right)$ \\
\hline \multicolumn{3}{|c|}{ Slope } \\
\hline foot per foot $(\mathrm{ft} / \mathrm{ft})$ & 5,280 & foot per mile ( $\mathrm{ft} / \mathrm{mi})$ \\
\hline
\end{tabular}

\section{Datum}

Vertical coordinate information is referenced to (1) stage, the height above an arbitrary datum established at a streamflow-gaging station, and (2) elevation, the height above the North American Vertical Datum of 1988 (NAVD 88).

Vertical coordinate information for historical data collected and stored as National Geodetic Vertical Datum of 1929 (NGVD 29) has been converted to NAVD 88 for this publication.

Conversion from NGVD 29 to NAVD 88 varies spatially and was done by using the North American Vertical Datum Conversion (VERTCON). This conversion generally is accurate within about \pm 0.5 feet. For additional information the reader is directed to Milbert (1999) and to the National Geodetic Survey (2019) website for the datum transformation utility VERTCON at https:// www.ngs.noaa.gov/cgi-bin/VERTCON/vert_con.prl.

Horizontal coordinate information is referenced to the North American Datum of 1983 (NAD 83).

Elevation, as used in this report, refers to distance above the vertical datum. 


\section{Abbreviations}

$\begin{array}{ll}\text { AHPS } & \text { Advanced Hydrologic Prediction Service } \\ \text { DEM } & \text { digital elevation model } \\ \text { FEMA } & \text { Federal Emergency Management Agency } \\ \text { FIS } & \text { flood insurance study } \\ \text { HEC-RAS } & \text { Hydrologic Engineering Center River Analysis System } \\ \text { lidar } & \text { light detection and ranging } \\ \text { NAD 83 } & \text { North American Datum of 1983 } \\ \text { NAVD 88 } & \text { North American Vertical Datum of 1988 } \\ \text { NGVD 29 } & \text { National Geodetic Vertical Datum of 1929 } \\ \text { NWIS } & \text { National Water Information System } \\ \text { NWS } & \text { National Weather Service } \\ \text { RMSE } & \text { root mean square error } \\ \text { USACE } & \text { U.S. Army Corps of Engineers } \\ \text { USGS } & \text { U.S. Geological Survey } \\ \text { VERTCON } & \text { North American Vertical Datum Conversion }\end{array}$




\title{
Flood-Inundation Maps for a 23-Mile Reach of the Medina River at Bandera, Texas, 2018
}

\author{
By Namjeong Choi and Frank L. Engel
}

\section{Abstract}

In 2018, the U.S. Geological Survey (USGS), in cooperation with the Bandera County River Authority and Groundwater District and the Texas Water Development Board, studied floods through the period of record to create a library of flood-inundation maps for the Medina River at Bandera, Texas. Digital flood-inundation maps for a 23-mile reach of the Medina River at and near Bandera, from the confluence with Winans Creek to English Crossing Road, were developed. The flood-inundation maps depict estimates of the areal extent and depth of flooding corresponding to a range of different gage heights (gage height is commonly referred to as "stage," or the water-surface elevation at a streamflow-gaging station) at USGS streamflow-gaging station 08178880 Medina River at Bandera, Tex. (hereinafter referred to as the "Bandera station"). Water-surface profiles were computed for the stream reach by means of a onedimensional step-backwater model. The stage-discharge (streamflow) relation effective in 2018 was used to calibrate the model, and stages from four recent flood events were used to independently validate the model. The calibrated hydraulic model was then used to compute 29 water-surface profiles for stages at 1-foot ( $\mathrm{ft}$ ) increments referenced to the station datum and ranging from $10 \mathrm{ft}$ (near bankfull) to $38 \mathrm{ft}$, which exceeds the major flood stage of the National Weather Service Advanced Hydrologic Prediction Service of $24 \mathrm{ft}$. The simulated water-surface profiles were then combined with a geographic information system digital elevation model (derived from light detection and ranging data having a 0.4 -ft vertical accuracy and 1.6-ft horizontal resolution) to delineate the area flooded for stages ranging from 10 to $38 \mathrm{ft}$.

The digital flood-inundation maps are delivered through the USGS Flood Inundation Mapper application that presents map libraries and provides detailed information on floodinundation extents and stages for modeled sites. The floodinundation maps developed in this study, in conjunction with the real-time stage data from the Bandera station, are intended to help guide the public in taking individual safety precautions and provide emergency management personnel with a tool to efficiently manage emergency flood operations and post-flood recovery efforts.

\section{Introduction}

The town of Bandera is on the banks of the Medina River in Bandera County in south-central Texas. The residents of Bandera County and the town of Bandera have experienced several severe floods, including devasting floods in 1978, 2002, and 2015. In Bandera County, the Medina River is generally a perennial stream; during the period of record (1983-2018), the median annual streamflow of the Medina River at U.S. Geological Survey (USGS) streamflow-gaging station 08178880 Medina River at Bandera, Tex. (hereinafter referred to as the "Bandera station"), was 83.1 cubic feet per second ( $\left.\mathrm{ft}^{3} / \mathrm{s}\right)$ (table 1; U.S. Geological Survey, 2018a). During May 1997-September 2018, the median monthly gage height (commonly referred to as "stage," or the watersurface elevation at a streamflow-gaging station; Rantz and others, 1982) at the Bandera station was 4.15 feet (ft) (U.S. Geological Survey, 2018a). The most recent large peak discharge at the Bandera station was $46,700 \mathrm{ft}^{3} / \mathrm{s}$ on May 23, 2015; the corresponding peak stage was $24.94 \mathrm{ft}$ (table 1; U.S. Geological Survey, 2018a). The 2015 peak stage, although much smaller than the 1978 and 2002 peak stages, exceeded the major flood stage value of $24 \mathrm{ft}$ designated by the National Weather Service (NWS) (2018a). The estimated peak discharge and stage during the July 5, 2002, flood event at the Bandera station was $159,000 \mathrm{ft}^{3} / \mathrm{s}$ and $38.91 \mathrm{ft}$, respectively (table 1). On August 2, 1978, an estimated peak discharge of $281,000 \mathrm{ft}^{3} / \mathrm{s}$ and stage of $49.60 \mathrm{ft}$ were measured at nearby USGS streamflow-gaging station 08179000 Medina River near Pipe Creek, Tex., which is no longer in service (operation ceased in October 1982) (Caran and Baker, 1986; U.S. Geological Survey, 2018b).

Emergency responders in Bandera and surrounding communities currently (2019) rely on available online information sources to make decisions on how to best alert the public and mitigate flood damages. These sources of information include the USGS National Water Information System (NWIS), the Federal Emergency Management Agency (FEMA) flood insurance study (FIS) (Federal Emergency Management Agency, 2011), and the NWS Advanced Hydrologic Prediction Service (AHPS) (National Weather Service, 2018a). The NWS AHPS displays the USGS stage 
Table 1. U.S. Geological Survey streamflow-gaging station information for the Medina River at and near Bandera, Texas.

[Station location is shown in fig. 1. $\mathrm{mi}^{2}$, square mile; fts/s, cubic foot per second; ft, foot; NAVD 88, North American Vertical Datum of 1988. Data from U.S. Geological Survey, 2019]

\begin{tabular}{|c|c|c|c|c|c|c|c|c|}
\hline $\begin{array}{l}\text { Station } \\
\text { number }\end{array}$ & Station name & $\begin{array}{c}\text { Drainage } \\
\text { area } \\
\left(\mathrm{mi}^{2}\right)\end{array}$ & Latitude & Longitude & $\begin{array}{l}\text { Period of } \\
\text { peak-flow } \\
\text { record } \\
\text { (water } \\
\text { years }{ }^{1} \text { ) }\end{array}$ & $\begin{array}{l}\text { Median annual } \\
\text { streamflow } \\
\text { for the period } \\
\text { of record } \\
\left(\mathrm{ft}^{3} / \mathbf{s}\right)\end{array}$ & $\begin{array}{l}\text { Peak recorded } \\
\text { stage (ft), gage } \\
\text { datum and } \\
\text { elevation } \\
\text { (ft, NAVD 88) } \\
\text { and date }\end{array}$ & $\begin{array}{c}\text { Peak } \\
\text { discharge } \\
\left(f^{3} / \mathbf{s}\right) \\
\text { and date }\end{array}$ \\
\hline 08178861 & $\begin{array}{l}\text { North Prong Medina River at Brewington Creek } \\
\text { near Medina, Tex. }\end{array}$ & 91.1 & $29^{\circ} 52^{\prime} 31.2^{\prime \prime}$ & $99^{\circ} 20^{\prime} 55.8^{\prime \prime}$ & $\begin{array}{l}\text { Not available } \\
\text { (stage-only) }\end{array}$ & $\begin{array}{l}\text { Not available } \\
\quad \text { (stage-only) }\end{array}$ & $\begin{array}{c}9.15 \\
(1,625) \\
\text { October } 9,2018\end{array}$ & $\begin{array}{l}\text { Not available } \\
\text { (stage-only) }\end{array}$ \\
\hline 08178871 & $\begin{array}{l}\text { West Prong Medina River at Carpenter Creek } \\
\text { Road near Medina, Tex. }\end{array}$ & 25.2 & $29^{\circ} 46^{\prime} 48.5^{\prime \prime}$ & $99^{\circ} 22^{\prime} 45.4^{\prime \prime}$ & $\begin{array}{l}\text { Not available } \\
\text { (stage-only) }\end{array}$ & $\begin{array}{l}\text { Not available } \\
\quad \text { (stage-only) }\end{array}$ & $\begin{array}{c}3.71 \\
(1,650) \\
\text { October 9, } 2018\end{array}$ & $\begin{array}{l}\text { Not available } \\
\text { (stage-only) }\end{array}$ \\
\hline 0817887350 & Medina River at Patterson Road at Medina, Tex. & 227 & $29^{\circ} 47^{\prime} 38.01^{\prime \prime}$ & $99^{\circ} 14^{\prime} 54.94^{\prime \prime}$ & 2012-present & 47.8 & $\begin{array}{c}18.20 \\
(1,419) \\
\text { May } 23,2015\end{array}$ & $\begin{array}{c}2,500 \\
\text { May 24, } 2015\end{array}$ \\
\hline 08178880 & Medina River at Bandera, Tex. ${ }^{3}$ & 328 & $29^{\circ} 43^{\prime} 25^{\prime \prime}$ & $99^{\circ} 04^{\prime \prime} 11 "$ & 1983-present & 83.1 & $\begin{array}{c}38.91 \\
(1,189.82)^{4} \\
\text { July 5, } 2002\end{array}$ & $\begin{array}{c}159,000 \\
\text { July } 5,2002\end{array}$ \\
\hline 08178980 & $\begin{array}{l}\text { Medina River above English Crossing near } \\
\text { Pipe Creek, Tex. }\end{array}$ & 472 & $29^{\circ} 41^{\prime} 40^{\prime \prime}$ & $98^{\circ} 58^{\prime} 46^{\prime \prime}$ & 2018-present & 77.5 & $\begin{array}{c}14.77 \\
(1,158.00) \\
\text { September } 22,2018\end{array}$ & $\begin{array}{c}12,100 \\
\text { September } 22,2018\end{array}$ \\
\hline 08179000 & Medina River near Pipe Creek, Tex. & 474 & $29^{\circ} 40^{\prime} 31^{\prime \prime}$ & $99^{\circ} 58^{\prime} 33^{\prime \prime}$ & $\begin{array}{l}1922-1935, \\
1952-1975 \\
1975-1982\end{array}$ & 137.7 & $\begin{array}{c}49.60 \\
(1067.37) \\
\text { August 2, } 1978\end{array}$ & $\begin{array}{c}\text { 281,000 } \\
\text { August 2, } 1978\end{array}$ \\
\hline
\end{tabular}

${ }^{1}$ Water year is the 12 -month period from October 1 of one year through September 30 of the following year and is designated by the calendar year in which it ends.

${ }^{2}$ Peak discharge for the July 2, 2002, event estimated from a slope-area indirect computation.

${ }^{3}$ The most recent large peak discharge at this station was $46,700 \mathrm{ft}^{3} / \mathrm{s}$ on May 23, 2015; the corresponding peak stage was $24.94 \mathrm{ft}$.

${ }^{4}$ The official gage datum of the streamflow-gaging station is the National Geodetic Vertical Datum of 1929, and the conversion was made using the North American Vertical Datum Conversion (VERTCON) (Milbert, 1999; National Geodetic Survey, 2019). 
data and issues flood forecasts for the Bandera station during times of elevated streamflows. Although the USGS stream stage and the NWS AHPS flood-forecast information are particularly useful for residents in the immediate vicinity of a streamflow-gaging station, it is of limited use to residents farther upstream or downstream because the water-surface elevation is not constant along the stream reach. It is difficult to convert stage into depth and areal extent of flooding at points distant from the streamflow-gaging station.

To provide emergency responders in Bandera and surrounding communities with additional flood-planning and response tools, the USGS, in cooperation with the Bandera County River Authority and Groundwater District and the Texas Water Development Board, developed a hydraulic model to create a library of digital flood-inundation maps for a 23-mile (mi) reach of the Medina River near Bandera. Each map represents a different stream stage, resulting in a set of 29 maps referenced to different stages historically recorded at the Bandera station. The flood-inundation maps documented in this report and in its companion data release (Engel and Choi, 2019) will give decision makers new information for flood response and mitigation. By referring to the appropriate map, emergency responders can discern the severity of potential flooding (depth of water and areal extent), identify roads that are or will soon be flooded, and make plans for notification or evacuation of residents for some distance upstream and downstream from the streamflow-gaging station. In addition, the capability to visualize the potential extent of flooding may motivate residents to take precautions and heed warnings that they previously might have disregarded.

\section{Purpose and Scope}

The purpose of this report is to describe the development of a flood-inundation model and resulting maps for Bandera and other parts of Bandera County adjacent to a 23-mi reach of the Medina River (fig. 1). The maps were produced for flood levels referenced to the stage recorded at the Bandera station (table 1) on the Main Street (State Highway 173) bridge in the middle of the study reach. Twenty-nine maps of water-surface profiles were generated covering the range of stages for 1-ft increments from 10 to $38 \mathrm{ft}$. The $10-\mathrm{ft}$ stage represents approximately bankfull conditions for the Medina River at the Bandera station and is defined by the NWS as the "action stage," or that stage "which, when reached by a rising stream, represents the level where the NWS or a partner/user needs to take some type of mitigation action in preparation for possible significant hydrologic activity" (National Weather Service, 2018b). The 24-ft stage is defined by the NWS as the "major flooding" level or that stage which is characterized by "extensive inundation and property damage" and is usually characterized by "the evacuation of people and livestock and the closure of both primary and secondary roads" (National Weather Service, 2018b). The maximum stage value of $38 \mathrm{ft}$ corresponds to the approximate peak stage observed by the USGS at the Bandera station during the 2002 flood. The map library identifies areas likely to be flooded throughout a broad range of hydrologic conditions. Real-time streamflow data for the Bandera station support forecasts by the NWS that are used to guide the selection of appropriate flood-inundation maps.

\section{Study Area Description}

The study area includes a 23-mi reach of the Medina River that flows through Bandera, Tex., from the confluence with Winans Creek to English Crossing Road near Bandera in Bandera County (fig. 1). The study area is in the southeastern part of the Edwards Plateau (Hill, 1901). Steep terrain covers much of the study area; the soils are generally thin and rocky (U.S. Department of Agriculture, 1977). This rugged part of the Edwards Plateau is bounded by the Balcones Escarpment (Barker and others, 1994) (fig. 1). Outside of the flood plain, vegetation consists of grasslands interspersed with thick stands of Juniperus ashei (Ashe juniper), Quercus spp. (oak), and Prosopis spp. (mesquite) (Gould, 1975). The thin soils are composed mostly of clay derived from the limestone that forms the terrain (Barker and others, 1994). The terrain in the upstream part of the Medina River watershed is particularly steep - ranging on average from 6- to 8-percent slopes - and the thin, underdeveloped top soils make the area conducive to high-magnitude flash flooding (Caran and Baker, 1986). The slope in the 23-mile reach of the Medina River for which flood maps were developed is approximately 2 to 4 percent, with steeper slopes farther upstream in the headwaters. Abundant moisture from the Gulf of Mexico and terrain-related effects of the Balcones Escarpment make the area one of the most flood-prone regions of the United States (Caran and Baker, 1986; Slade and Patton, 2003; Nielsen and others, 2015).

The climate of Bandera County is classified as subtropical subhumid, and on average about 30 inches of precipitation falls each year (Larkin and Bomar, 1983). During August 1-3, 1978, more than 30 inches of rain fell on a large part of Bandera County when tropical storm Amelia moved inland from the Gulf of Mexico; during this storm, convective instability was enhanced by orographic lifting along the Balcones Escarpment (Schroeder and others, 1987). Since 1983, there have been at least 21 large-magnitude rainfall events producing flood stage greater than the NWS action stage of $10 \mathrm{ft}$ at the Bandera station (National Weather Service, 2018a; U.S. Geological Survey, 2018a). 

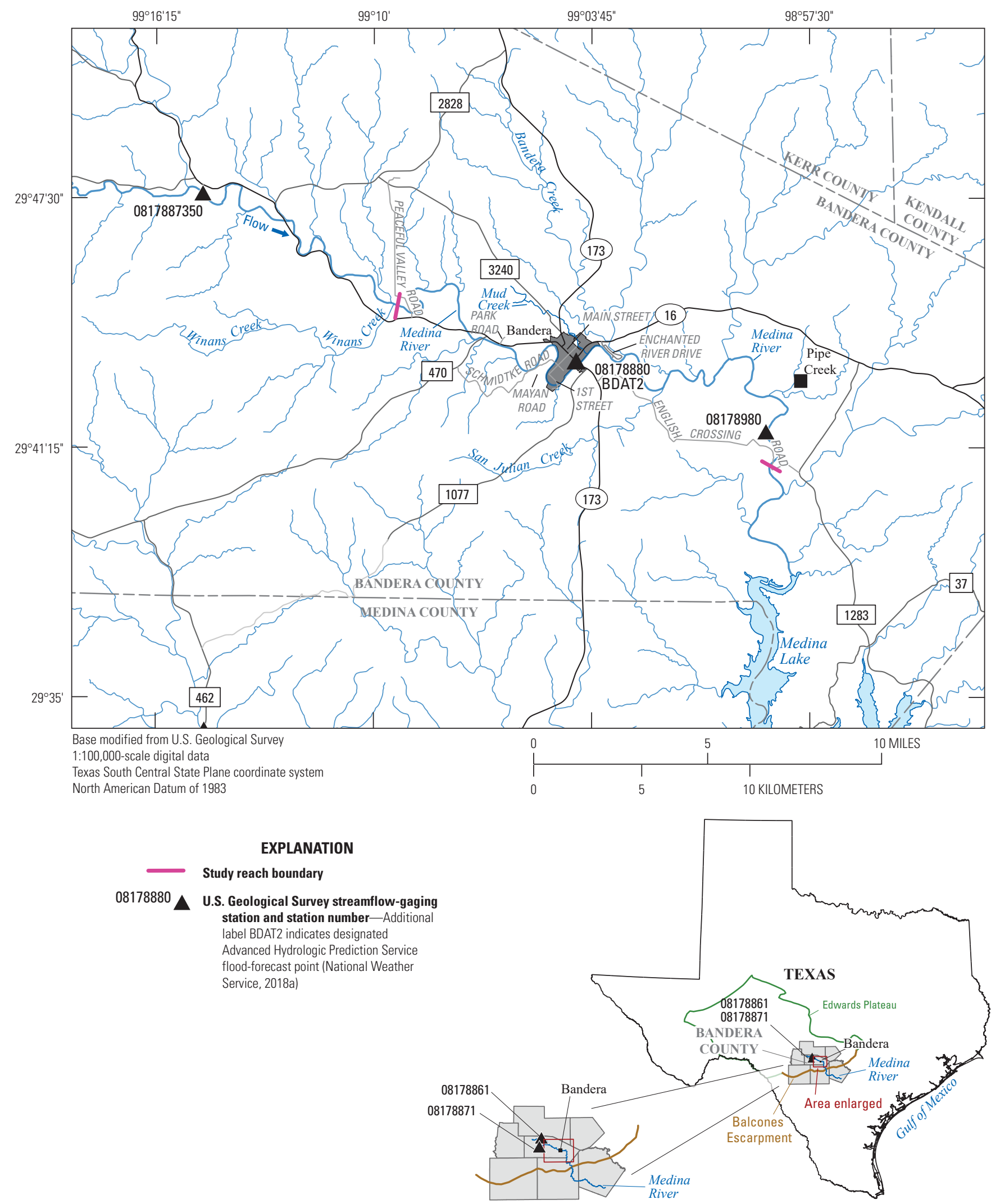

Figure 1. Location of the study reach on the Medina River at and near Bandera, Texas, and locations of the nearest U.S. Geological Survey streamflow-gaging stations. 
The drainage area of the Medina River is 293 square miles $\left(\mathrm{mi}^{2}\right)$ at the upstream extent of the study reach, $328 \mathrm{mi}^{2}$ at the Bandera station, and $474 \mathrm{mi}^{2}$ at the downstream extent of the study reach (table 1), which is just downstream from USGS streamflow-gaging station 08178980 Medina River above English Crossing near Pipe Creek, Tex. (hereinafter referred to as the "English Crossing station") (U.S. Geological Survey, 2018c) (fig. 1). Although there are no major tributaries to the Medina River in the study reach as it flows through Bandera, Bandera Creek (fig. 1) might become a source of appreciable streamflow during exceptionally large-magnitude rainfall events. The drainage areas of Bandera Creek and Mud Creek were delineated by the authors by using the ArcGIS Hydrology toolset (Esri, 2019a). The drainage area of Bandera Creek is about $62 \mathrm{mi}^{2}$. Normally dry Mud Creek also flows into the Medina River in Bandera (fig. 1). During large-magnitude rainfall events, Mud Creek often fills with an appreciable amount of water (fig. 2). Because the drainage area of Mud Creek is only about $2 \mathrm{mi}^{2}$, the creek is unlikely to be a source of appreciable streamflow, even during exceptionally largemagnitude rainfall events. Backwater from the Medina River likely fills Mud Creek during high-flow conditions, giving the appearance of appreciable inflows. The relatively higher water-surface elevation in the Medina River during flood events likely impedes streamflow entering from the mouth of Mud Creek, resulting in backwater in Mud Creek (Missouri Department of Transportation, 2019).

The study reach has an average top-of-bank channel width of about $180 \mathrm{ft}$ and an average channel slope of $0.002 \mathrm{ft} / \mathrm{ft}$
(10.6 ft/mi) (Engel and Choi, 2019). The main channel within the study reach is traversed by nine road crossings and lowwater crossings and there are two low-head dams.

Bandera is part of the rapidly growing San Antonio, Tex., metropolitan statistical area (U.S. Census Bureau, 2018). The population of Bandera County increased from 20,485 in 2010 to 22,824 in 2018 (U.S. Census Bureau, 2018). The population of Bandera was 857 in 2010, the most recent year for which the population was reported (U.S. Census Bureau, 2018).

\section{Previous Studies}

The FEMA FIS in effect currently (2019) for the Medina River in Bandera County (available on the FEMA Flood Map Service Center website [Federal Emergency Management Agency, 2019]) was made effective on February 4, 2011 (Federal Emergency Management Agency, 2011). The 2011 FIS provided information about the 1-percent and 0.2-percent annual exceedance probability water-surface profiles and associated flood-plain maps for the Medina River. Estimates of the discharges for the 10-percent, 2-percent, 1-percent, and 0.2-percent annual exceedance probability floods were documented for the Bandera station with discharges of 42,300 , $106,000,144,000$, and 265,000 ft $3 / \mathrm{s}$, respectively (listed under "upstream from the confluence of Bandera Creek" in table 2) (Federal Emergency Management Agency, 2011). The drainage area for this location was listed as $330 \mathrm{mi}^{2}$ (table 2) (Federal Emergency Management Agency, 2011) as compared to the USGS-reported value of $328 \mathrm{mi}^{2}$ (table 1).

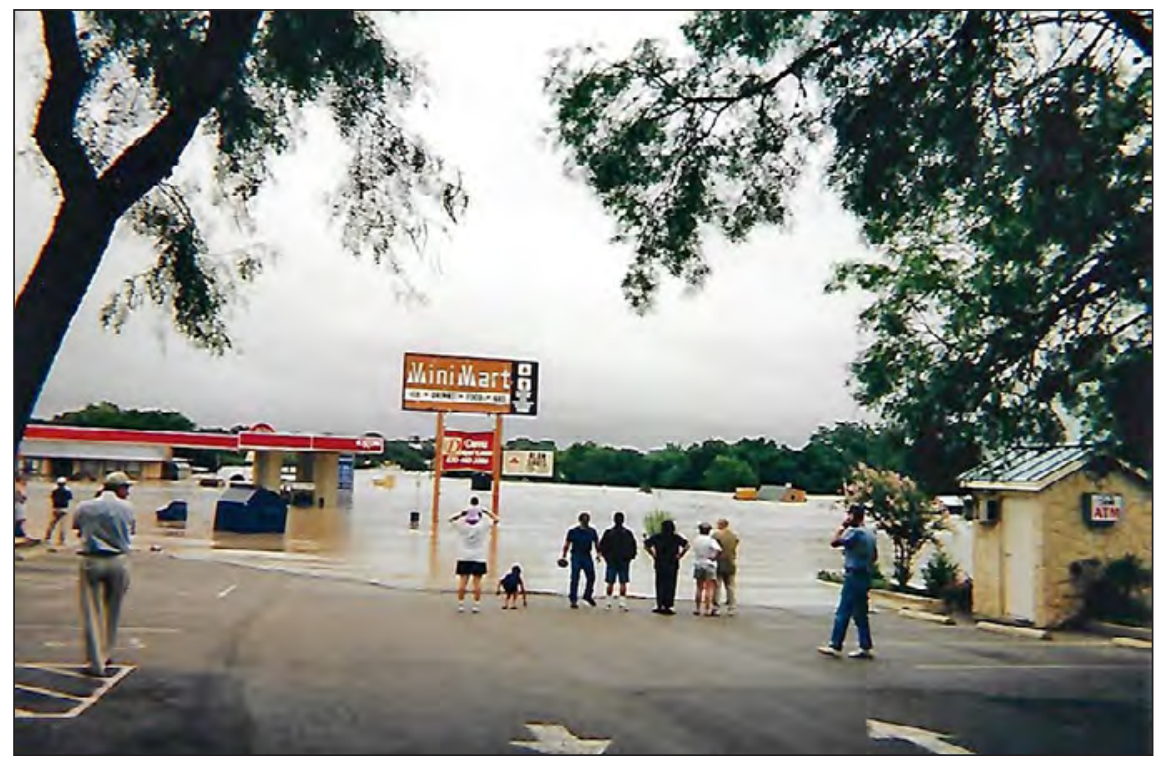

Figure 2. Northeast-oriented view of the Medina River in flood stage at State Route 16 near Bandera, Texas, July 2002 (photograph courtesy of Bandera County Honorable Judge Richard Evans). 
Table 2. Peak discharges for selected annual exceedance probabilities for the Medina River at and near Bandera, Texas.

$\left[\mathrm{mi}^{2}\right.$, square mile; $\mathrm{ft}^{3} / \mathrm{s}$, cubic foot per second. Data from Federal Emergency Management Agency, 2011]

\begin{tabular}{|c|c|c|c|c|c|}
\hline \multirow{2}{*}{ Location on Medina River } & \multirow{2}{*}{$\begin{array}{c}\text { Drainage } \\
\text { area } \\
\left(\mathrm{mi}^{2}\right)\end{array}$} & \multicolumn{4}{|c|}{$\begin{array}{l}\text { Estimated discharges }\left(\mathrm{ft}^{3} / \mathrm{s}\right) \text { for indicated } \\
\text { annual exceedance probabilities }\end{array}$} \\
\hline & & $\begin{array}{c}10 \\
\text { (percent) }\end{array}$ & $\begin{array}{c}2 \\
\text { (percent) }\end{array}$ & $\begin{array}{c}1 \\
\text { (percent) }\end{array}$ & $\begin{array}{c}0.2 \\
\text { (percent) }\end{array}$ \\
\hline Upstream from confluence with San Julian Creek & 416 & 48,042 & 120,467 & 163,653 & 301,167 \\
\hline Downstream from confluence with Bandera Creek & 397 & 46,500 & 116,600 & 158,400 & 291,500 \\
\hline Upstream from the confluence of Bandera Creek ${ }^{1}$ & 330 & 42,300 & 106,000 & 144,000 & 265,000 \\
\hline
\end{tabular}

${ }^{1}$ This location corresponds to the U.S. Geological Survey streamflow-gaging station number 08178880 Medina River at Bandera, Tex.

\section{Creation of Flood-Inundation Map Library}

The USGS has standardized the procedures for developing flood-inundation maps for flood-prone communities (U.S. Geological Survey, 2018d) so that the process that is used and the resulting products are similar regardless of which USGS office is responsible for the work. Tasks specific to the development of the flood maps for Bandera were as follows: (1) collect and compile topographic and bathymetric data for selected cross sections and geometric data for structures and bridges along the study reach;

(2) estimate energy-loss factors (roughness coefficients) in the stream channel and flood plains and determine steady-state streamflow data; (3) compute water-surface profiles by using the U.S. Army Corps of Engineers (USACE) Hydrologic Engineering Center River Analysis System (HEC-RAS) computer program (U.S. Army Corps of Engineers, 2016a); (4) produce estimated flood-inundation maps at various stages by using the HEC-RAS computer program and Esri ArcGIS (Esri, 2019b), and (5) prepare flood-inundation maps, both as shapefile polygons that depict the areal extent of flood inundation and as depth grids that provide the depth of floodwaters, for display on a USGS flood-inundation mapping application (U.S. Geological Survey, 2018d).

A related task in conjunction with the development of the flood maps for Bandera was to upgrade USGS streamflow-gaging station 0817887350 Medina River at Patterson Road at Medina, Tex. (fig. 1; hereinafter referred to as the "Patterson Road station"), to include continuous measurements of stage. Data from the Patterson Road station were not used for flood-inundation map creation. In addition to upgrading the Patterson Road station, two new flood warning stations were installed on the Medina River upstream from the Patterson Road station: USGS streamflow-gaging station 08178861 North Prong Medina River at Brewington Creek near Medina, Tex., and USGS streamflow-gaging station 08178871 West Prong Medina River at Carpenter Creek Road near Medina, Tex. (fig. 1).

\section{Computation of Water-Surface Profiles}

The water-surface profiles used to develop the 29 floodinundation maps in this study were computed using HECRAS, version 5.0.6 (U.S. Army Corps of Engineers, 2016a, b). The HEC-RAS model is applicable to a wide range of scenarios, from large networks of regulated or unregulated streams or rivers to constructed channels (U.S. Army Corps of Engineers, 2016b), and is a one-dimensional step-backwater model for simulation of water-surface profiles with steady- or unsteady-state streamflow computation options (Davidian, 1984; U.S. Army Corps of Engineers, 2016a).

\section{Hydrologic Data}

The study reach encompasses two USGS streamflowgaging stations, the Bandera station and the English Crossing station (fig. 1; table 1). The Bandera station has been in operation since October 1982. Since May 1987, continuous stage data at the Bandera station have been measured every 15 minutes, transmitted hourly to a satellite, and made available on the internet through the USGS NWIS web interface (U.S. Geological Survey, 2018a). The English Crossing station has been recording continuous stage data since it began operation in May 2017. Stage data from the stations are referenced to local vertical datums. The Bandera station stage values were converted from this local datum to water-surface elevations referenced to the North American Vertical Datum of 1988 (NAVD 88) by adding 1,189.82 ft. The official datum of the Bandera station is the National Geodetic Vertical Datum of 1929 (NGVD 29), and the datum of the station $1,189.46 \mathrm{ft}$ above NGVD 29 was converted to NAVD 88 by using the North American Vertical Datum Conversion (VERTCON) available from the National Geodetic Survey website (Milbert, 1999; National Geodetic Survey, 2019). Continuous records of streamflow for the Bandera station are computed from stage-discharge relations (rating curves) developed and periodically updated for the streamflowgaging station as additional discharge measurements are made. 
Rating curves are updated when erosion or deposition of bed sediment causes the channel hydraulic conditions to change (Rantz and others, 1982). Information from the Bandera station, including historical stages, and streamflow records, including annual peak streamflows, are available through the USGS NWIS web interface (U.S. Geological Survey, 2018a). Because of the short period of data collection at the English Crossing station, May 2017-present (2019), the initial stagedischarge rating curve for this streamflow-gaging station is still being developed.

The streamflows used in the model simulations (table 3) were obtained from the stage-discharge rating curve that was in use at the Bandera station as of June 15, 2018 (rating curve number 11.0), and corresponded with the 29 observed stages used to model streamflow profiles. Streamflows of Bandera Creek - the one tributary that might become a source of appreciable streamflow in the study reach during exceptionally large-magnitude rainfall events - were estimated on the basis of discharge values estimated for the Medina River just upstream from Bandera Creek and just downstream from Bandera Creek corresponding to four annual exceedance probability floods (the 10-percent, 2-percent, 1-percent, and 0.2 -percent of annual exceedance probability floods published in the FEMA FIS) (table 4 in Federal Emergency Management Agency, 2011). Bandera Creek streamflow for the four annual exceedance probabilities were then extrapolated to obtain additional estimates of Bandera Creek streamflow for the 29 modeled streamflow profiles. The streamflow adjustment within the study reach was enabled by using the flow change location feature in HEC-RAS (U.S. Army Corps of Engineers, 2016b). Stage and discharge data from the Bandera station were used to develop the flood-inundation maps, augmented by additional cross-section information obtained from the English Crossing station. Because the English Crossing station was only recently installed in 2017, the period of record was not sufficient to use stage-discharge rating curve data from this site in the development of the flood-inundation model.

\section{Topographic and Bathymetric Data}

All topographic data used in this study are referenced vertically to NAVD 88 and horizontally to the North American Datum of 1983 (NAD 83). Cross-section elevation data were obtained from a digital elevation model (DEM) that was derived from light detection and ranging (lidar) data that were collected from December 18, 2013, to January 25, 2014, during low-flow conditions (Texas Natural Resources Information System, 2014). The lidar data have horizontal resolution of $1.6 \mathrm{ft}$ and vertical accuracy of $0.4 \mathrm{ft}$ at a 95 -percent confidence level for the open terrain land-cover category (root mean square error [RMSE] of $0.2 \mathrm{ft}$ ) (Texas Natural Resources Information System, 2014).
Table 3. Estimated discharges at the upstream end of the study reach and at the confluence of Bandera Creek with the Medina River, Texas, that were used in the hydraulic model and corresponding stages and water-surface elevations at U.S. Geological Survey streamflow-gaging station 08178880 Medina River at Bandera, Texas.

[ft, foot; NAVD 88, North American Vertical Datum of 1988; $\mathrm{ft}^{3} / \mathrm{s}$, cubic foot per second]

\begin{tabular}{|c|c|c|c|}
\hline \multirow{2}{*}{$\begin{array}{l}\text { Stage of } \\
\text { water- } \\
\text { surface } \\
\text { profile } \\
\text { (ft) }\end{array}$} & \multirow{2}{*}{$\begin{array}{c}\text { Water-surface } \\
\text { elevation } \\
\text { (ft, NAVD 88) }\end{array}$} & \multicolumn{2}{|c|}{$\begin{array}{l}\text { Estimated discharge } \\
\text { at indicated location } \\
\qquad\left(\mathrm{ft}^{3} / \mathrm{s}\right)\end{array}$} \\
\hline & & $\begin{array}{l}\text { Upstream end } \\
\text { of study reach }\end{array}$ & $\begin{array}{c}\text { Bandera } \\
\text { Creek } \\
\text { confluence }\end{array}$ \\
\hline 10 & $1,199.82$ & 2,370 & 2,370 \\
\hline 11 & $1,200.82$ & 3,090 & 3,100 \\
\hline 12 & $1,201.82$ & 3,940 & 4,040 \\
\hline 13 & $1,202.82$ & 5,220 & 5,450 \\
\hline 14 & $1,203.82$ & 6,730 & 7,110 \\
\hline 15 & $1,204.82$ & 8,500 & 9,060 \\
\hline 16 & $1,205.82$ & 10,500 & 11,300 \\
\hline 17 & $1,206.82$ & 12,800 & 13,800 \\
\hline 18 & $1,207.82$ & 15,400 & 16,700 \\
\hline 19 & $1,208.82$ & 18,300 & 19,900 \\
\hline 20 & $1,209.82$ & 21,500 & 23,400 \\
\hline 21 & $1,210.82$ & 25,100 & 27,300 \\
\hline 22 & $1,211.82$ & 29,000 & 31,600 \\
\hline 23 & $1,212.82$ & 33,300 & 36,300 \\
\hline 24 & $1,213.82$ & 37,900 & 41,400 \\
\hline 25 & $1,214.82$ & 42,900 & 47,000 \\
\hline 26 & $1,215.82$ & 48,300 & 52,900 \\
\hline 27 & $1,216.82$ & 54,200 & 59,400 \\
\hline 28 & $1,217.82$ & 60,400 & 66,200 \\
\hline 29 & $1,218.82$ & 67,100 & 73,600 \\
\hline 30 & $1,219.82$ & 74,200 & 81,400 \\
\hline 31 & $1,220.82$ & 81,800 & 89,800 \\
\hline 32 & $1,221.82$ & 89,800 & 98,600 \\
\hline 33 & $1,222.82$ & 98,300 & 108,000 \\
\hline 34 & $1,223.82$ & 107,000 & 118,000 \\
\hline 35 & $1,224.82$ & 117,000 & 128,000 \\
\hline 36 & $1,225.82$ & 127,000 & 139,000 \\
\hline 37 & $1,226.82$ & 137,000 & 151,000 \\
\hline 38 & $1,227.82$ & 148,000 & 163,000 \\
\hline
\end{tabular}

${ }^{1}$ Water-surface profiles are 1-ft increments of stage, referenced to the gage datum of U.S. Geological Survey streamflow-gaging station 08178880 Medina River at Bandera, Tex. 
Through the use of HEC-RAS (U.S. Army Corps of Engineers, 2016b), which utilizes a set of procedures, tools, and utilities for processing geospatial data in ArcGIS, elevation data were extracted from the DEM for 366 cross sections in the 23-mi study reach and subsequently input to the HEC-RAS model. The lidar dataset used in this study was collected during lowflow conditions - the average of 31 daily stage values collected at the Bandera station in December 2013 was $3.87 \mathrm{ft}$, with a standard deviation of $0.06 \mathrm{ft}$, whereas the long-term average daily December stage is $4.32 \mathrm{ft}$ based on the 18 available years of record from 1997 through 2018 (U.S. Geological Survey, 2018a) — which enabled the lidar coverage to include much of the channel bottom. However, lidar data cannot provide ground elevations below a stream's water-surface; thus, channel cross sections were surveyed by USGS field crews at two locations during March 2017 to include the submerged part of the channel bottom and determine the thalweg elevations (figs. 3-4). Cross-section depths were measured by wading at the Bandera and English Crossing stations. The average of 31 daily stage values collected at the Bandera station during the survey in March 2017 was $4.47 \mathrm{ft}$, with a standard deviation of $0.10 \mathrm{ft}$, as compared to the stage value collected during the lidar surveys of $3.87 \mathrm{ft}$ (Texas Natural Resources Information System, 2014; U.S. Geological Survey, 2018a). A surveying level system was used to measure the elevation of the channel bottom at each surveyed cross section. At both surveyed locations, the average maximum water depth was $1.6 \mathrm{ft}$ (Engel and Choi, 2019). Thus, the upstream and downstream cross sections of each river crossing structure were lowered by $1.6 \mathrm{ft}$; this assumes the same low-flow water-surface elevations measured during the channel cross-section surveys existed during the collection of the lidar data.

\section{Hydraulic Structures}

Eleven structures in the study reach, consisting of nine road crossings from upstream to downstream (Peaceful Valley Road, State Route 16, State Route 470, Park Road, Schmidtke Road, 1st Street, Main Street, a private road off Enchanted River Drive, and English Crossing Road) and two low-head dams (the first is 1,100 ft upstream from the Schmidtke Road crossing, and the second is $165 \mathrm{ft}$ upstream from the Bandera station) (fig. 1), have the potential to affect water-surface elevations along the stream during floods. During March 14-15, 2017, USGS personnel completed field surveys to obtain channel-geometry data at each of the 11 structures by using an electronic digital level and a fiberglass barcode rod (figs. 3-4). Standard USGS surveying methods for stream channels were used (Kenney, 2010). Each hydraulic structure is associated with energy losses caused by the contraction or expansion of the cross-section area from one cross section to the next. The energy-loss coefficients are defined as multipliers of the difference in velocity heads from upstream to downstream cross sections. The default energy-loss coefficients for contraction and expansion are set to 0.1 and 0.3 , and they were adjusted to 0.3 and 0.5 in the bounding cross sections of each hydraulic structure to address the abrupt change of cross sections near the structures (U.S. Army Corps of Engineers, 2016a). Channel geometry at each structure and corresponding energy-loss coefficients were input to the hydraulic model.

\section{Energy-Loss Factors}

Hydraulic analyses require the estimation of energy losses that result from frictional resistance exerted by a channel on flow. These energy losses are quantified by the Manning's roughness coefficient (" $n$ " value). Initial (precalibration) $n$ values were selected on the basis of field observations as described by Benson and Dalrymple (1967), high-resolution aerial photographs, insights provided in Conyers and Fonstad (2005) on selecting $n$ values, and by using the Cowan method for estimating $n$ values (Cowan, 1956). The study reach of the Medina River has a mixed bedrock and gravel channel bed with sections of straight channel and large meander bends (figs. 3-4). The flood plain along the channel was often moderately steep, irregular, and typically composed of bedrock. Grasses, Salix spp. (willows), different types of oak trees, Ashe juniper, and Taxodium distichum sp. (bald cypress) trees grow in the flood plain. Vegetation type and density change markedly throughout the flood plain, creating large variation in flood-plain roughness values. As a result, each cross section was subdivided into three parts for assignment of $n$ values: main channel, left-bank flood plain, and right-bank flood plain. A composite $n$ value $(0.05)$ that is thought to represent the diverse energy-loss factors of these land types was used for the initial estimates of the main channel, left-bank flood plain, and right-bank floodplain $n$ values. As part of the calibration process, the initial $n$ values were adjusted until the differences between simulated and observed water-surface elevations at the Bandera station were minimized. The final $n$ values ranged from 0.050 to 0.064 for the main channel and from 0.052 to 0.075 for the flood-plain areas modeled in this analysis. The average $n$ values for the main channel, left-bank flood plain, and rightbank flood plain were $0.055,0.061$, and 0.060 , respectively.

\section{Hydraulic Model}

HEC-RAS simulations were done by using the steadystate flow computation option in the hydraulic model (U.S. Army Corps of Engineers, 2016a, b). Steady-state hydraulic data used in the simulations consisted of the streamflow regime, boundary conditions, and peak streamflows that produced modeled water-surface elevations at the streamflowgaging station cross section that matched water-surface elevations of the target stages (target water-surface elevations) (Chow, 1959). The target water-surface elevations coincided with the twenty-nine 1-ft increments of stage, referenced to the local streamflow-gaging station datum. A subcritical (tranquil) streamflow and "normal depth" option were used as downstream boundary conditions for the hydraulic model. 


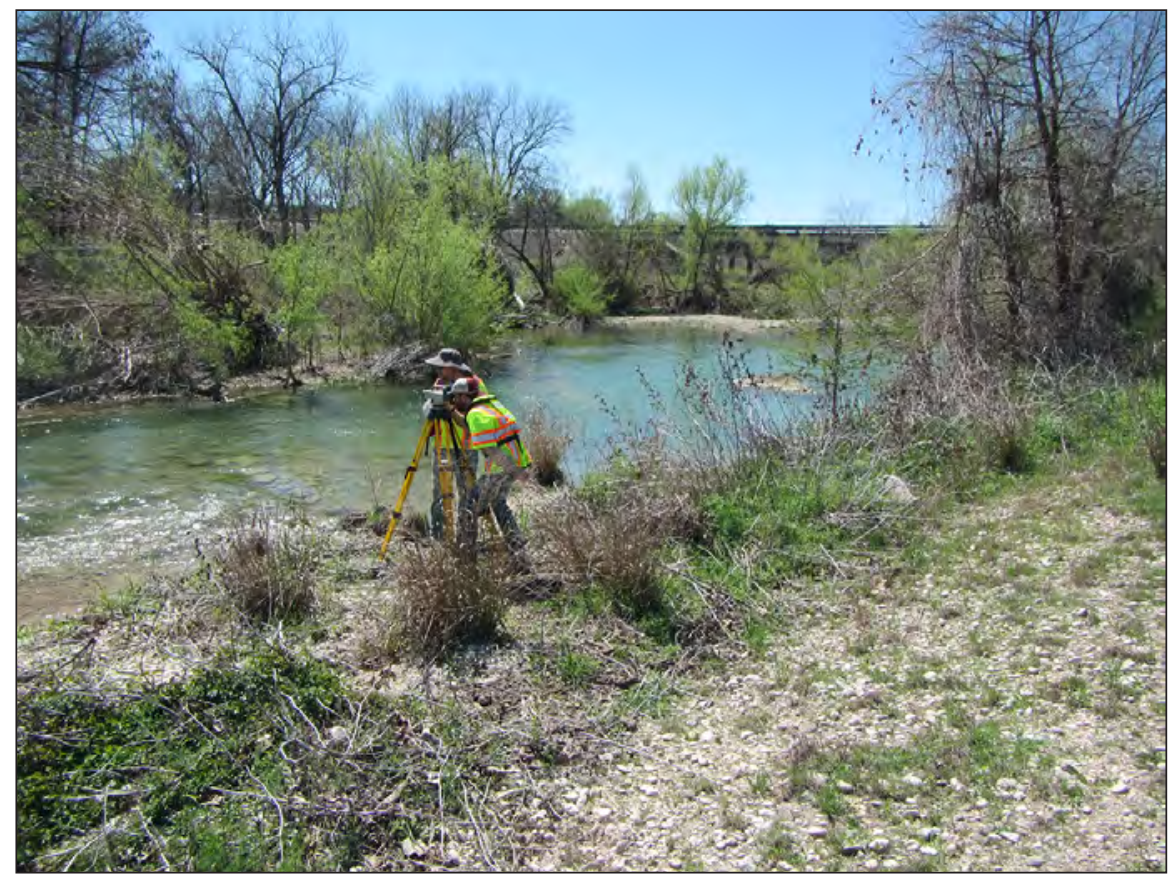

Figure 3. U.S. Geological Survey (USGS) crews performing a cross-section survey near USGS streamflow-gaging station 08178880 Medina River at Bandera, Texas. View is toward the south from the left bank of the Medina River, and Main Street bridge is shown in the background.

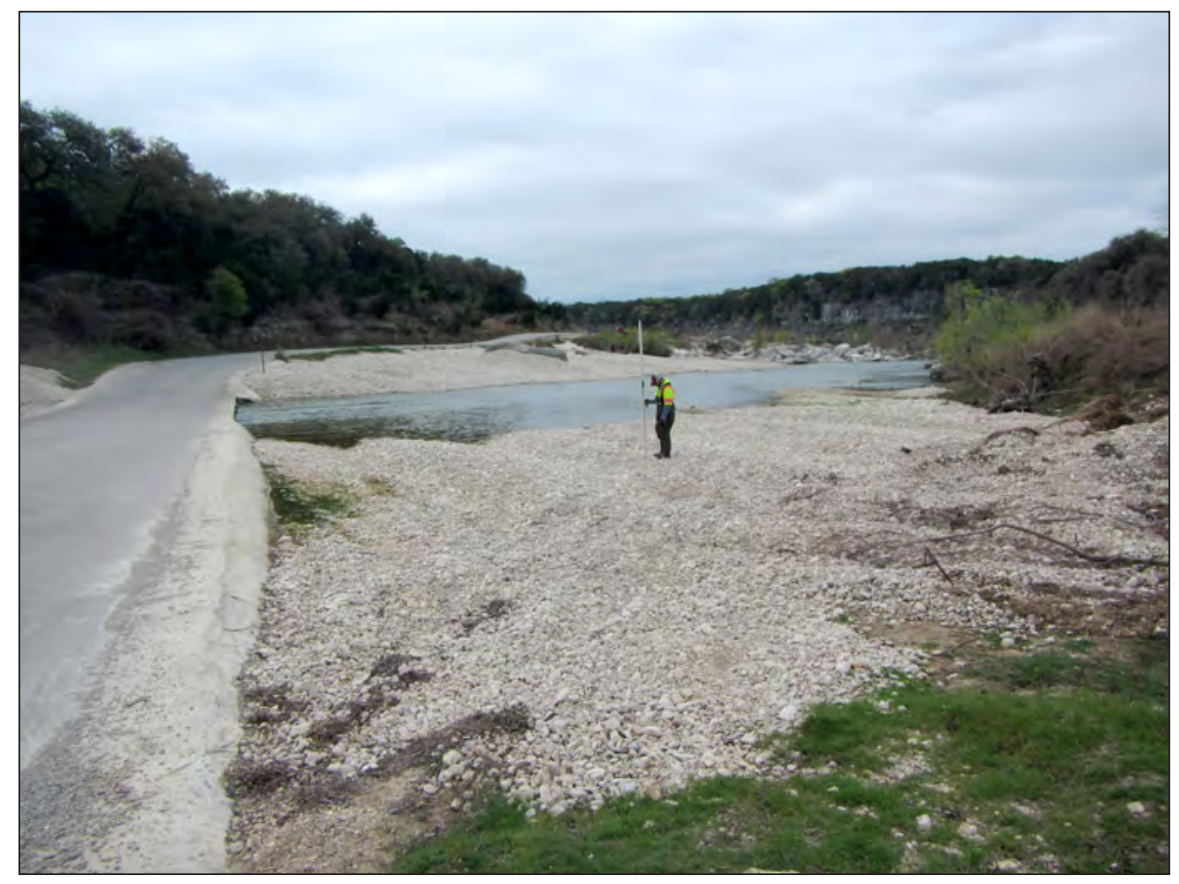

Figure 4. U.S. Geological Survey (USGS) crews performing a cross-section survey at USGS streamflow-gaging station 08178980 Medina River above English Crossing near Pipe Creek, Texas. View is toward the south from the right bank of the Medina River. 
The estimated average water-surface slope of $0.002 \mathrm{ft} / \mathrm{ft}$ $(10.6 \mathrm{ft} / \mathrm{mi})$ from data contained in the FEMA FIS (Federal Emergency Management Agency, 2011) was used for the normal depth boundary condition. The peak streamflows that were used in the model are discussed in the section "Hydrologic Data."

The hydraulic model was calibrated by adjusting the $n$ values until the results of the hydraulic computations closely agreed with the observed water-surface elevations for given streamflows. A total of 29 streamflow profiles, corresponding to stages from 10 to $38 \mathrm{ft}$ at 1 - $\mathrm{ft}$ increments, were used for the calibration (table 3 ). Differences between observed and modeled water-surface elevations for the 29 simulated streamflows at the Bandera station were equal to or less than $0.48 \mathrm{ft}$ with an RMSE of $0.28 \mathrm{ft}$ (table 4). The results demonstrate that the model is capable of simulating accurate water-surface elevations (within $0.5 \mathrm{ft}$ of observed) over a wide range of streamflows in the study reach.

The model results were compared to the stages of four recent flood events at Bandera station and FEMA FIS watersurface elevations. The observed stages for the four flood events (March 20, 2012; May 26, 2014; May 23, 2015; and May 29, 2016) were compared to the modeled water-surface elevations. The range of the observed stages was from 10.85 to $24.94 \mathrm{ft}$ for these recent flood events. For the 2012, 2014, 2015, and 2016 floods, modeled stages overestimated observed stages by $0.35,0.42,0.71$, and $0.63 \mathrm{ft}$, respectively (table 5). The calibrated model was also compared to the FEMA FIS (Federal Emergency Management Agency, 2011) water-surface elevation profile of 1-percent annual exceedance probability flood, which includes the study area. The average difference between the FEMA FIS water-surface elevations and the modeled water-surface elevations from Mayan Road to San Julian Creek (fig. 1) was $0.68 \mathrm{ft}$, and the average difference in water depths was similar, $0.70 \mathrm{ft}$ (Federal Emergency Management Agency, 2011), providing additional evidence that the calibrated model was able to represent watersurface elevations during flood events in the study area.

\section{Development of Water-Surface Profiles}

The calibrated HEC-RAS model was used to generate water-surface profiles for the 23-mi study reach for 29 stages from 10 to $38 \mathrm{ft}$ at $1-\mathrm{ft}$ increments as referenced to the local datum of the Bandera station. These stages correspond to water-surface elevations of $1,199.82 \mathrm{ft}$ and $1,227.82 \mathrm{ft}$ at the Bandera station, referenced to NAVD 88. These modeling stages include the NWS action stage and major flood stage explained in the "Purpose and Scope" section of this report.
Table 4. Target water-surface elevations and modeled watersurface elevations used to calibrate the model at U.S. Geological Survey streamflow-gaging station 08178880 Medina River at Bandera, Texas.

[ft, foot; NAVD 88, North American Vertical Datum of 1988]

\begin{tabular}{|c|c|c|c|}
\hline $\begin{array}{c}\text { Stage of } \\
\text { water- } \\
\text { surface } \\
\text { profile } \\
\text { (ft) }\end{array}$ & $\begin{array}{l}\text { Target water- } \\
\text { surface } \\
\text { elevation } \\
\text { (ft, NAVD 88) }\end{array}$ & $\begin{array}{c}\text { Modeled } \\
\text { water-surface } \\
\text { elevation } \\
\text { (ft, NAVD 88) }\end{array}$ & $\begin{array}{c}\text { Difference } \\
\text { in elevation } \\
\text { (ft) }\end{array}$ \\
\hline 10 & $1,199.82$ & $1,199.87$ & 0.05 \\
\hline 11 & $1,200.82$ & $1,200.61$ & -0.21 \\
\hline 12 & $1,201.82$ & $1,201.35$ & -0.47 \\
\hline 13 & $1,202.82$ & $1,202.34$ & -0.48 \\
\hline 14 & $1,203.82$ & $1,203.35$ & -0.47 \\
\hline 15 & $1,204.82$ & $1,204.40$ & -0.42 \\
\hline 16 & $1,205.82$ & $1,205.41$ & -0.41 \\
\hline 17 & $1,206.82$ & $1,206.42$ & -0.40 \\
\hline 18 & $1,207.82$ & $1,207.45$ & -0.37 \\
\hline 18 & $1,208.82$ & $1,208.50$ & -0.32 \\
\hline 20 & $1,209.82$ & $1,209.54$ & -0.28 \\
\hline 21 & $1,210.82$ & $1,210.55$ & -0.27 \\
\hline 22 & $1,211.82$ & $1,211.57$ & -0.25 \\
\hline 23 & $1,212.82$ & $1,212.60$ & -0.22 \\
\hline 24 & $1,213.82$ & $1,213.61$ & -0.21 \\
\hline 25 & $1,214.82$ & $1,214.69$ & -0.13 \\
\hline 26 & $1,215.82$ & $1,215.78$ & -0.04 \\
\hline 27 & $1,216.82$ & $1,216.95$ & 0.13 \\
\hline 28 & $1,217.82$ & $1,218.17$ & 0.35 \\
\hline 29 & $1,218.82$ & $1,219.14$ & 0.32 \\
\hline 30 & $1,219.82$ & $1,219.95$ & 0.13 \\
\hline 31 & $1,220.82$ & $1,220.81$ & -0.01 \\
\hline 32 & $1,221.82$ & $1,221.79$ & -0.03 \\
\hline 33 & $1,222.82$ & $1,222.73$ & -0.09 \\
\hline 34 & $1,223.82$ & $1,223.67$ & -0.15 \\
\hline 35 & $1,224.82$ & $1,224.70$ & -0.12 \\
\hline 36 & $1,225.82$ & $1,225.67$ & -0.15 \\
\hline 37 & $1,226.82$ & $1,226.61$ & -0.21 \\
\hline 38 & $1,227.82$ & $1,227.60$ & -0.22 \\
\hline
\end{tabular}

${ }^{1}$ Root mean square error (RMSE) difference in elevations for all profiles is $0.28 \mathrm{ft}$. 
Table 5. Observed stages and modeled stages for four flood events (March 20, 2012; May 26, 2014; May 23, 2015; and May 29, 2016) used for validation of the model at U.S. Geological Survey streamflow-gaging station 08178880 Medina River at Bandera, Texas.

[ft, foot; NAVD 88, North American Vertical Datum of 1988; $\mathrm{ft}^{3} / \mathrm{s}$, cubic foot per second]

\begin{tabular}{|c|c|c|c|c|c|c|c|}
\hline \multicolumn{2}{|c|}{$\begin{array}{c}3 / 20 / 2012 \text { flood } \\
\text { (discharge }=9,860 \mathrm{ft}^{3} / \mathrm{s} \text { ) }\end{array}$} & \multicolumn{2}{|c|}{$\begin{array}{c}5 / 26 / 2014 \text { flood } \\
\text { (discharge }=3,640 \mathrm{ft}^{3} / \mathrm{s} \text { ) }\end{array}$} & \multicolumn{2}{|c|}{$\begin{array}{c}5 / 23 / 2015 \text { flood } \\
\text { (discharge }=46,700 \mathrm{ft}^{3} / \mathrm{s} \text { ) }\end{array}$} & \multicolumn{2}{|c|}{$\begin{array}{c}\text { 5/29/2016 flood } \\
\text { (discharge }=26,400 \mathrm{ft}^{3} / \mathrm{s} \text { ) }\end{array}$} \\
\hline $\begin{array}{l}\text { In ft above } \\
\text { streamgage } \\
\text { datum }\end{array}$ & $\begin{array}{l}\text { In ft above } \\
\text { NAVD } 88\end{array}$ & $\begin{array}{c}\text { In ft above } \\
\text { streamgage } \\
\text { datum }\end{array}$ & $\begin{array}{l}\text { In } \mathrm{ft} \text { above } \\
\text { NAVD } 88\end{array}$ & $\begin{array}{c}\text { In ft above } \\
\text { streamgage } \\
\text { datum }\end{array}$ & $\begin{array}{l}\text { In } \mathrm{ft} \text { above } \\
\text { NAVD } 88\end{array}$ & $\begin{array}{c}\text { In ft above } \\
\text { streamgage } \\
\text { datum }\end{array}$ & $\begin{array}{c}\text { In } \mathrm{ft} \text { above } \\
\text { NAVD } 88\end{array}$ \\
\hline \multicolumn{8}{|c|}{ Observed stage } \\
\hline 14.93 & $1,204.75$ & 10.85 & $1,200.67$ & 24.94 & $1,214.76$ & 20.44 & $1,210.26$ \\
\hline 15.28 & $1,205.10$ & 11.27 & $1,201.09$ & 25.65 & $1,215.47$ & 21.07 & $1,210.89$ \\
\hline \multicolumn{8}{|c|}{ Difference between modeled and observed stage, in ft } \\
\hline 0.35 & 0.35 & 0.42 & 0.42 & 0.71 & 0.71 & 0.63 & 0.63 \\
\hline
\end{tabular}

\section{Development of Flood-Inundation Maps}

Flood-inundation maps were developed for a 23-mi study reach of the Medina River that includes the Bandera station, which is a designated AHPS flood-forecast point with the NWS site identifier BDAT2 (fig. 1) (National Weather Service, 2018a). The 29 water-surface elevation profiles were combined with the DEM data to develop the flood-inundation maps by using RAS Mapper, a geographic information system extension of the HEC-RAS program (U.S. Army Corps of Engineers, 2016a, b). The DEM data were derived from the lidar data described in the section "Topographic and Bathymetric Data" and have an estimated vertical accuracy of $0.4 \mathrm{ft}$ (plus or minus $0.2 \mathrm{ft}$ ). Shapefile polygons and depth grids of the flood-inundation extents for each of the 29 profiles were modified, as required, in the ArcMap application of Esri ArcGIS (Esri, 2019b) to ensure that the water-surface elevations transition smoothly at the flood boundaries between modeled cross sections, with the upstream water-surface elevation at one cross section generally higher than the downstream water-surface elevation at the next cross section (backwater conditions sometimes result in no change in elevation between cross sections or a slight increase in water-surface elevation between the upstream and downstream cross sections).

The HEC-RAS model utilizes ineffective streamflow areas in locations that could potentially be inundated during a flood but because of the topography or adjacent obstructions would not convey water. Typically, ineffective flow areas describe regions where water ponds and has little to no downstream velocity. The way in the model to compensate for ineffective area is the hydraulic computations include ineffective areas in storage calculations but exclude the areas from the active flow. Once the modeled watersurface elevation rises above the elevation of an ineffective streamflow area, all excess area above the ineffective area is used to contribute to the conveyance of streamflow.
Inundated areas that were detached from the main channel were examined to identify possible subsurface connections with the main river, such as through culverts under roadways. Where such connections existed, the mapped inundated areas were retained in their respective floodinundation maps; otherwise, inundated areas detached from the main channel were deleted from the extent of the floodinundation maps. The final flood-inundation extents were then overlaid on a georeferenced topography map of the study area and made available on the interactive USGS Flood Inundation Mapper application described in the "Flood Inundation Map Delivery and Use" section of this report. One item of note concerning these images is that bridge surfaces are displayed as inundated regardless of the actual water-surface elevation in relation to the lowest structural chord of the bridge or the bridge deck. Estimates of water depth can be obtained from the depth grid data that are included with the presentation of the flood-inundation maps on the Flood Inundation Mapper application. The flood-inundation map corresponding to the highest simulated water-surface profile, a stage of $38 \mathrm{ft}$, is presented in figure 5 .

Road crossings at Peaceful Valley Road, State Route 470, Park Road, Schmidtke Road, 1st Street, a private road off Enchanted River Drive, and English Crossing Road (fig. 1) are inundated for all modeled stages. This inundation indicates that each of these structures is adversely affected prior to the stage at the Bandera station reaching the NWS action stage of $10 \mathrm{ft}$. There are two bridges that are not inundated when the river stage at the Bandera station reaches the NWS major flood stage of $24 \mathrm{ft}$ : State Route 16 and Main Street bridges. However, water overtops the State Route 16 bridge at a stage of $27 \mathrm{ft}$ at the Bandera station according to the model results. Model results show the Main Street bridge becoming submerged when the Bandera station stage is $31 \mathrm{ft}$. 


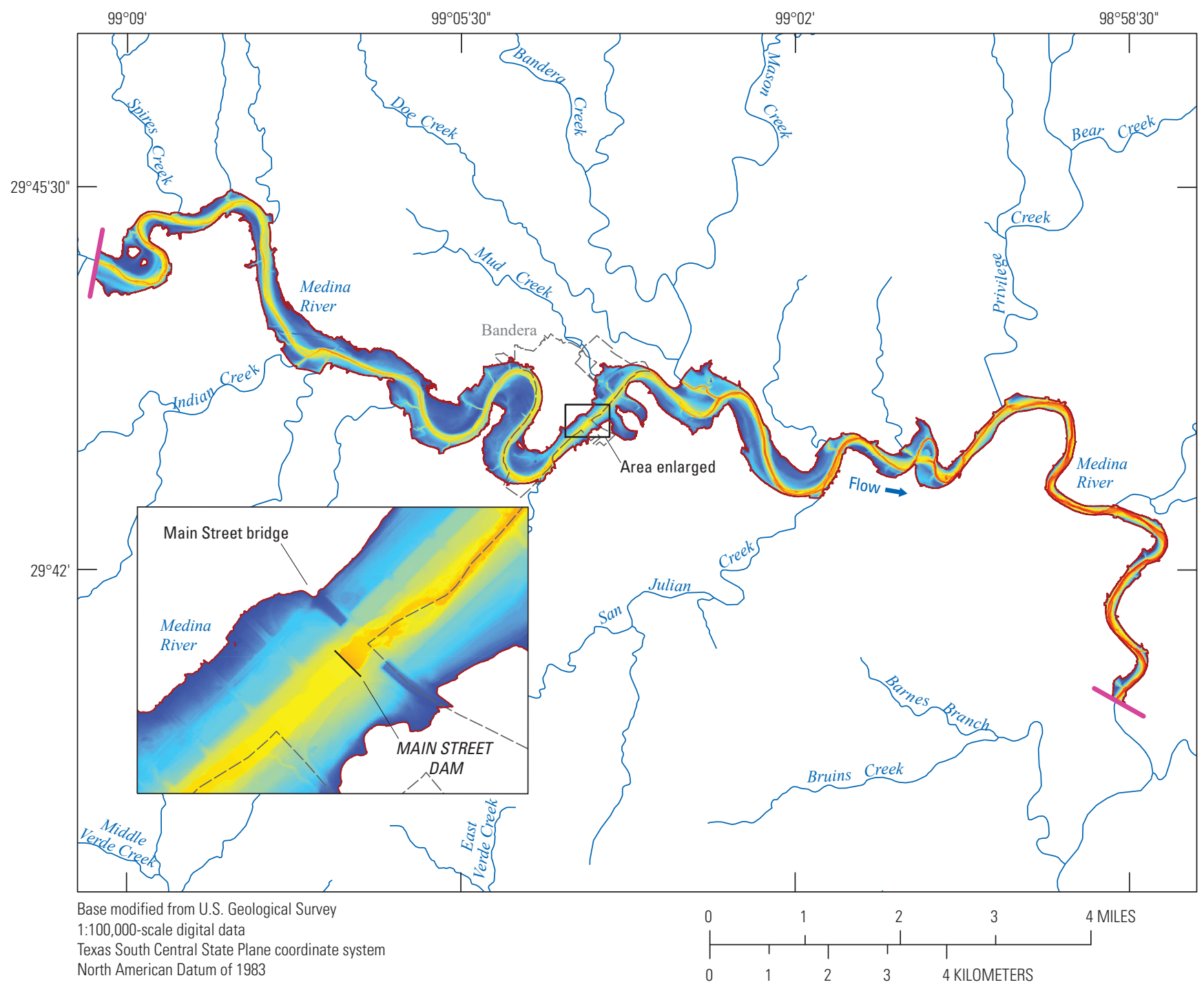

EXPLANATION

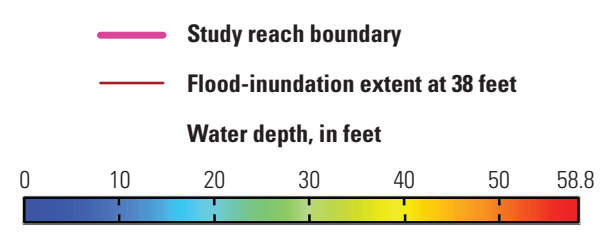

Figure 5. The modeled flood-inundation map for the Medina River at Bandera, Texas, corresponding to a stage of 38 feet at U.S. Geological Survey streamflow-gaging station 08178880. 


\section{Flood-Inundation Map Delivery and Use}

The flood-inundation extent polygons, depth grids, and study area boundaries are available in Engel and Choi (2019). The USGS Flood Inundation Mapping Program website (U.S. Geological Survey, 2018d) provides USGS flood-inundation study information to the public. The website links to the Flood Inundation Mapper application that presents map libraries and provides detailed information on flood-inundation extents and stages for modeled sites (https://wimcloud.usgs.gov/apps/FIM/ FloodInundationMapper.html). During a modeled flood event in the application, the Bandera station on the map viewer will become active, and a user can select the site to open a separate window that includes further details. The detailed window provides the real-time stage and streamflow at the Bandera station in the USGS NWIS web interface tab and predicted stage in the NWS AHPS flood forecasting tab.

The estimated flood-inundation maps are displayed in sufficient detail (1-ft depth increments) so that emergency response decisions are informed in real-time, and preparations for potential flooding can be made. Depending on the flood magnitude, roadways are shown as shaded (inundated and likely impassable) or not shaded (dry and passable) to facilitate emergency planning and use. Bridges are shaded - that is, shown as inundated - regardless of the flood magnitude. The flood-inundation maps were developed for the main reach of the Medina River from the Winans Creek confluence to English Crossing Road. Any tributaries that contribute to the Medina River were not modeled; thus, flood-inundation extents for tributaries are not available. Therefore, roadways over tributaries that are not shaded are not necessarily dry and passible. A shaded building should not be interpreted to mean that the structure is completely submerged but rather that the land surfaces near the building are inundated. In these instances, the water depth (as indicated in the mapping application by holding the cursor over an inundated area) near the building would be an estimate of the water depth inside the structure, unless flood-proofing measures had been implemented.

\section{Disclaimer for Flood-Inundation Maps}

The flood-inundation maps should not be used for navigation, regulatory, permitting, or other legal purposes. The USGS provides these maps "as is" for a quick reference, emergency planning tool but assumes no legal liability or responsibility resulting from the use of this information.

\section{Uncertainties and Limitations Regarding Use of Flood-Inundation Maps}

Although the flood-inundation maps represent the boundaries of inundated areas with a distinct line, some uncertainty is associated with these maps. The flood boundaries shown were estimated on the basis of water stages (water-surface elevations) and streamflows at the Bandera station. Water-surface elevations along the stream reaches were estimated by steady-state hydraulic modeling, assuming unobstructed flow, and using streamflows and hydrologic conditions anticipated at the USGS streamflow-gaging station. The hydraulic model reflects the land-cover characteristics and any bridge, dam, levee, or other hydraulic structures that existed as of March 2017. Meteorological factors (timing and distribution of precipitation) may cause actual streamflows along the modeled reach to vary from those assumed during a flood, which may lead to deviations from the water-surface elevations and inundation boundaries shown. Additional areas may be flooded when unanticipated changes occur in the hydraulic conditions such as changes in the streambed elevation or roughness, backwater into major tributaries along the study reach, or backwater from localized debris jams. The accuracy of the flood-inundation extent portrayed on these maps will vary with the accuracy of the DEM used to simulate the land surface. The user should be aware that the simulated 23-mi reach of the Medina River was calibrated to a single streamflow-gaging station at Bandera. Estimated flood-inundation extents inherently include uncertainty based on many factors, including the accuracy of input flood-plain elevation data, cross-sectional survey quality, and distance from model calibration and validation locations among other things.

If this series of flood-inundation maps are used in conjunction with NWS river forecasts, the user should be aware of additional uncertainties that may be inherent in or factored into NWS forecast procedures. The NWS uses forecast models to estimate the quantity and timing of water flowing through selected stream reaches in the United States. These forecast models (1) estimate the amount of runoff generated by precipitation; (2) simulate the movement of floodwater as it proceeds downstream; and (3) predict the flow and stage (and water-surface elevation) for the stream at a given location (AHPS forecast point) throughout the forecast period (every 6 hours and 3-5 days out in many locations). More information on AHPS forecasts is available at https:// water.weather.gov/ahps/about/about.php.

\section{Summary}

In 2019, the U.S. Geological Survey (USGS), in cooperation with the Bandera County River Authority and Groundwater District and the Texas Water Development Board, completed an assessment of floods through 2018 to create a library of flood-inundation maps for the Medina River in a reach at Bandera, Texas. A series of 29 digital flood-inundation maps were developed using data collected at USGS streamflow-gaging station 08178880 Medina River at Bandera, Tex. (hereinafter referred to as the "Bandera station"). The flood-inundation maps cover a 23-mile reach of the Medina River from the confluence with Winans Creek 
to English Crossing Road. The flood-inundation maps were developed by using the U.S. Army Corps of Engineers (USACE) Hydrologic Engineering Center River Analysis System (HEC-RAS) program to compute water-surface profiles and delineate estimated flood-inundation extents and depths of flooding for selected gage heights (gage height is commonly referred to as "stage," or the water-surface elevation at a streamflow-gaging station). The stage-discharge relation for the Bandera station was used to calibrate the model, and the stages from four recent floods (March 20, 2012; May 26, 2014; May 23, 2015; and May 29, 2016) were used to independently validate the model. Differences between observed and modeled water-surface elevations for the 29 simulated stages at the Bandera station were equal to or less than $0.48 \mathrm{ft}$ with a root mean square error of $0.28 \mathrm{ft}$.

The calibrated model was used to compute 29 watersurface profiles for stages at 1-foot (ft) increments referenced to the Bandera station datum and ranging from $10 \mathrm{ft}$ (near bankfull) to $38 \mathrm{ft}$, which exceeds the major flood stage of the National Weather Service Advanced Hydrologic Prediction Service of $24 \mathrm{ft}$. The modeled water-surface profiles were then combined with a geographic information system digital elevation model (derived from light detection and ranging data having a $0.4-\mathrm{ft}$ vertical accuracy and $1.6-\mathrm{ft}$ horizontal resolution) to delineate the area flooded for stages ranging from 10 to $38 \mathrm{ft}$. The final flood-inundation extents were then overlaid on a georeferenced topography map of the study area.

The digital flood-inundation maps are delivered through the USGS Flood Inundation Mapper application that presents map libraries and provides detailed information on floodinundation extents and stages for modeled sites (https:// wimcloud.usgs.gov/apps/FIM/FloodInundationMapper. $\mathrm{html})$. The flood-inundation maps developed in this study, in conjunction with the real-time stage data from the Bandera station, are intended to help guide the public in taking individual safety precautions and provide emergency management personnel with a tool to efficiently manage emergency flood operations and post-flood recovery efforts.

\section{References Cited}

Barker, R.A., Bush, P.W., and Baker, E.T.J., 1994, Geologic history and hydrogeologic setting of the Edwards-Trinity aquifer system, west-central Texas: U.S. Geological Survey Water-Resources Investigations Report 94-4039, 51 p.

Benson, M.A., and Dalrymple, T., 1967, General field and office procedures for indirect discharge measurements: U.S. Geological Survey Techniques of Water-Resources Investigations, book 3, chap. A1, 30 .

Caran, S.C., and Baker, V.R., 1986, Flooding along the Balcones Escarpment, central Texas, in Abbott, P.L., and Woodruff, C.M., eds., The Balcones Escarpment: Geological Society of America, p. 1-14.
Chow, V.T., 1959, Open channel hydraulics: New York, McGraw-Hill, 680 p.

Conyers, M.M., and Fonstad, M.A., 2005, The unusual channel resistance of the Texas Hill Country and its effect on flood flow Predictions: Physical Geography, v. 26, no. 5, p. 379-395.

Cowan, W.L., 1956, Estimating hydraulic roughness coefficients: Agricultural Engineering, v. 37, no. 7, p. 473475 .

Davidian, J., 1984, Computation of water-surface profiles in open channels: U.S. Geological Survey Techniques of Water-Resources Investigations, book 3, chap. A15, 48 p., accessed July 11, 2019, at https://pubs.usgs.gov/twri/ twri3-a15/pdf/TWRI_3-A15.pdf.

Engel, F.L., and Choi, N., 2019, Geospatial and survey data for flood-inundation maps in a 23-mile reach of the Medina River at Bandera, Texas, 2018: U.S. Geological Survey data release, https://doi.org/10.5066/P9WYD6LS.

Esri, 2019a, An overview of the Hydrology toolset: Esri, Inc., accessed May 17, 2019, at http://desktop.arcgis.com/en/ arcmap/10.5/tools/spatial-analyst-toolbox/an-overview-ofthe-hydrology-tools.htm.

Esri, 2019b, ArcGIS: Esri, Inc., website, accessed May 17, 2019, at https://www.esri.com/software/arcgis/.

Federal Emergency Management Agency, 2011, Flood insurance study, Bandera County Texas, and incorporated areas; effective February 4, 2011: Washington, D.C., Federal Emergency Management Agency, 40 p., 17 pls., accessed June 28, 2019, at https://msc.fema.gov/portal/ advanceSearch.

Federal Emergency Management Agency, 2019, FEMA Flood Map Service Center: Federal Emergency Management Agency website, accessed May 17, 2019, at https://msc. fema.gov/portal/.

Gould, F.W., 1975, Texas plants-A checklist and ecological summary: College Station, Tex., Texas A\&M University, Texas Agricultural Experiment Station, MP-585, 121 p.

Hill, R.T., 1901, Geography and geology of the Black and Grand Prairies, Texas with detailed descriptions of the Cretaceous formations and special reference to artesian waters: Twenty-first annual report of the United States Geological Survey to the Secretary of the Interior, 18991900, Part VII-Texas, 666 p.

Kenney, T.A., 2010, Levels at gaging stations: U.S. Geological Survey Techniques and Methods 3-A19, 60 p., accessed July 11, 2019, at https://pubs.usgs.gov/tm/tm3A19/pdf/ tm3A19.pdf. 
Larkin, T.J., and Bomar, G.W., 1983, Climatic atlas of Texas: Texas Department of Water Resources, Limited Printing Report LP-192, 151 p.

Milbert, D.G., 1999, National Geodetic Survey height conversion methodology, VERTCON: National Geodetic Survey web page, accessed May 13, 2019, at http://www.ngs. noaa.gov/TOOLS/Vertcon/vert_method.html.

Missouri Department of Transportation, 2019, Engineering policy guide - Structure and hydraulics: Missouri Department of Transportation, accessed September 15, 2011, at http://epg.modot.org/index.php?title=748.4_Headwater_ and Backwater.

National Geodetic Survey, 2019, Orthometric height conversion: National Geodetic Survey, accessed April 30, 2019, at https://www.ngs.noaa.gov/cgi-bin/VERTCON/ vert_con.prl.

National Weather Service, 2018a, Medina River at Bandera, Texas: National Weather Service Advanced Hydrologic Prediction Service website, accessed June 20, 2018, at https://water.weather.gov/ahps2/hydrograph. php?wfo=ews\&gage $=$ bdat 2 .

National Weather Service, 2018b, National Weather Service glossary: National Weather Service web page, accessed April 17, 2018, at http://w1.weather.gov/glossary.

Nielsen, E.R., Schumacher, R.S., and Keclik, A.M., 2015, The effect of the Balcones Escarpment on three cases of extreme precipitation in central Texas: American Meteorological Society Monthly Weather Review, v. 144, p. 119-138, accessed May 9, 2019, at https://doi.org/10.1175/MWR-D15-0156.1.

Rantz, S.E., and others, 1982, Measurement and computation of streamflow-Volume 1, measurement of stage and discharge: U.S. Geological Survey Water-Supply Paper 2175, 284 p., accessed May 8, 2019, at https://doi. org/10.3133/wsp2175_vol1.

Schroeder, E.E., Massey, B.C., and Chin, E.H., 1987, Floods in central Texas, August 1-4, 1978: U.S. Geological Survey Professional Paper 1332, 39 p., accessed May 10, 2019, at https://pubs.usgs.gov/pp/1332/report.pdf.

Slade, R.M., Jr., and Patton, J.M., 2003, Major and catastrophic storms and floods in Texas-215 major and 41 catastrophic events from 1953 to September 1, 2002: U.S. Geological Survey Open-File Report 2003-193, accessed May 8, 2019, at https://pubs.usgs.gov/of/2003/ofr03-193/.

Texas Natural Resources Information System, 2014, Strategic Mapping Program (StratMap) Bandera \& Lampasas Counties lidar 2014: Texas Natural Resources Information System, accessed May 14, 2019, at https://data.tnris.org/ collection/9dabb50e-00a1-46e5-8966-8a54ac424de6.
U.S. Army Corps of Engineers, 2016a, HEC-RAS-River analysis system-Hydraulic reference manual (ver. 5.0, February 2016): U.S. Army Corps of Engineers, 547 p., accessed May 14, 2019, at https://www.hec.usace.army.mil/ software/hec-ras/documentation/HEC-RAS\%205.0\%20 Reference\%20Manual.pdf.

U.S. Army Corps of Engineers, 2016b, HEC-RAS - River analysis system-User's manual (ver. 5.0, February 2016): U.S. Army Corps of Engineers, 962 p., accessed May 14, 2019, at https://www.hec.usace.army.mil/SOFTWARE/ hec-ras/documentation/HEC-RAS\%205.0\%20Users $\% 20$ Manual.pdf.

U.S. Census Bureau, 2018, American FactFinder: U.S. Census Bureau database, accessed April 18, 2018, at http:// factfinder2.census.gov.

U.S. Department of Agriculture, 1977, Soil survey of Bandera County, Texas: U.S. Department of Agriculture, Soil Conservation Service, in cooperation with Texas Agricultural Experimental Station, 71 p., accessed July 2, 2019, at https://www.nrcs.usda.gov/Internet/FSE_ MANUSCRIPTS/texas/TX019/0/Bandera.pdf.

U.S. Geological Survey, 2018a, USGS 08178880 Medina River at Bandera, TX, in USGS water data for the Nation: U.S. Geological Survey National Water Information System database, accessed April 17, 2018, at https:// doi.org/10.5066/F7P55KJN. [Site information directly accessible at https://waterdata.usgs.gov/tx/nwis/ inventory/?site_no=08178880]

U.S. Geological Survey, 2018b, USGS 08179000 Medina River near Pipe Creek, TX, in USGS water data for the Nation: U.S. Geological Survey National Water Information System database, accessed April 17, 2018, at https://doi.org/10.5066/F7P55KJN. [Site information directly accessible at https://waterdata.usgs.gov/tx/nwis/ inventory/?site_no $=08179000$.]

U.S. Geological Survey, 2018c, USGS 08178980 Medina River above English Crossing near Pipe Creek, TX, in USGS water data for the Nation: U.S. Geological Survey National Water Information System database, accessed April 17, 2018, at https://doi.org/10.5066/F7P55KJN. [Site information directly accessible at https://waterdata.usgs. gov/tx/nwis/inventory/?site_no $=08178980$.]

U.S. Geological Survey, 2018d, USGS Flood Inundation Mapping Program: U.S. Geological Survey website, accessed April 18, 2018, at https://water.usgs.gov/osw/ flood_inundation.

U.S. Geological Survey, 2019, USGS water data for the Nation: U.S. Geological Survey National Water Information System database, accessed April 10, 2019, at https://doi. org/10.5066/F7P55KJN. 
For more information about this publication, contact

Director, Texas Water Science Center

U.S. Geological Survey

1505 Ferguson Lane

Austin, TX 78754-4501

For additional information visit

https://www.usgs.gov/centers/tx-water.

Publishing support provided by Lafayette Publishing Service Center 


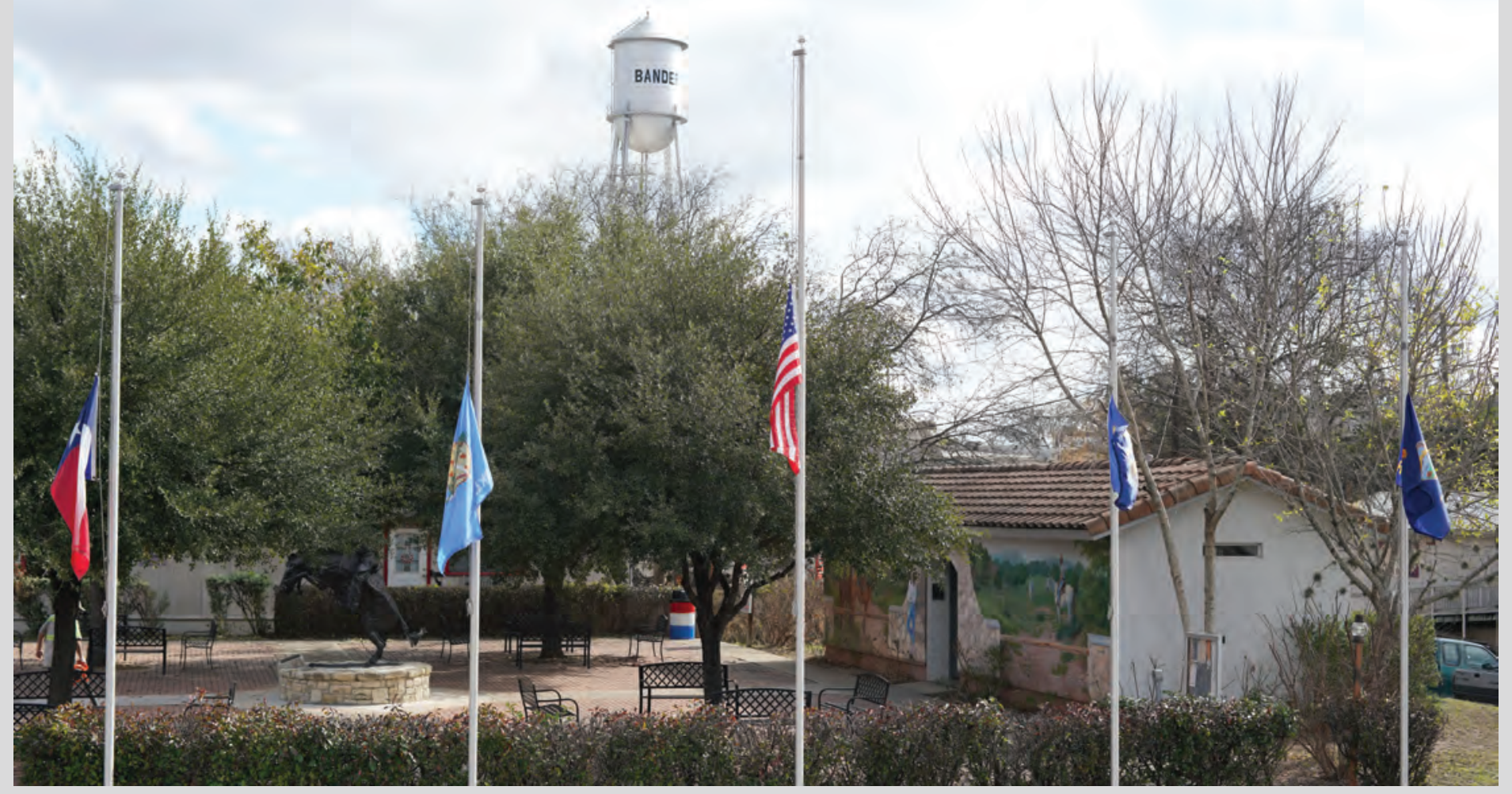

